\title{
The Importance of Dutch and German 19th Century Sources Baier PM
}

FIA, W.-Fr.-Laur-Weg 6, 72379 Hechingen, Germany

*Corresponding author: Baier PM, FIA, W.-Fr.-Laur-Weg 6, 72379 Hechingen, Germany, Tel: 07471-1489; E-mail: mh.baier@t-online.de

Received date: July 03, 2017; Accepted date: July 29, 2017; Published date: Aug 15, 2017

Copyright: (c) 2017 Baier PM. This is an open-access article distributed under the terms of the Creative Commons Attribution License, which permits unrestricted use, distribution, and reproduction in any medium, provided the original author and source are credited.

\section{The Importance of Dutch and German}

The most recent publications of the Kaharingan Religion in Central Kalimantan claim on the statement, that the original tribal religion of the Dayak Ngaju is the oldest religion of the world and the most original, orthodox and standing religion of mankind. God himself manifested this religion as the world religion that is the "compass", the guiding line for human life; and in the future probably Kaharingan will propagate upon the whole mankind. ${ }^{1}$ Thus many educated Dayaks from Central Kalimantan are convinced that the Kaharingan Religion is an equivalent monotheistic high religion as the Islam and Christianity. The former pastor and lecturer with the theological academy STTGKE in Banjarmasin, Dr. Marko Mahin, urges the churches, especially the GKE Church to do penance and confess their fault of discrimination against the Dayak religion and culture.

But is this Kaharingan religion really a homogeneous doctrine from the very beginning of mankind? Educated Dayaks in Southern Borneo only know Schaerer's Ngaju Religion from 1963 except oral traditions from their ancestors. So much older written sources tell a quite other stay of the Ngaju tribal religion. Author do select two sources only, a Dutch and a German one.

The Dutch historian on "Indie"-history, J. Pijnappel, - actually the German geologist and metallurgist $\mathrm{H}$. van Gaffron, whose language and writings confused the Dutch scientist - wrote a very profound essay on Southern Borneo. ${ }^{2}$ Von Gaffron travelled 1853 in the western part of South Borneo and collected important facts/material about nature, people, history and religion. He reports, that before 1846 the Dayak tribe were politically and economically independent and bartered with their own ships with Singapore. ${ }^{3}$ The vassalage and dependence upon the ruling house of Banjarmasin and Kotawaringin began with the appearance of a certain Raja Tanga (before 1680 a. Chr.). ${ }^{4} \mathrm{He}$ was of princely birth from Johor and tried to rule Seruyan ${ }^{5}$ Sampit in the Kotawaringin area. Raja Tanga had only one descendant, the Princess Putri Bui. She married a Banjarmasin prince. Therefore the kingdom of Banjarmasin got influence on the western part of Southern Borneo and the independence of the Dayak tribes ended. ${ }^{6}$ These historical facts are legendary, but they are the earliest hints to the famous Putri Junjung Buih, the ancestress of the Banjar kingdom. ${ }^{7}$ In many Malayan and Indonesian princely chronicles one found Putri Junjung Buih as an ancestress of regional kingdoms, at least from Sumatra/Malaya until the Celebes Sea. ${ }^{8}$ According to Overbecks translation the Sejarah Malayu narrates: "Once upon a day a mass of foam came floating down from the upper waters of the river. Inside of the foam there was a nice small girl, which was adopted by the ruler" (i.e. Sang Si Perba of Palembang) "and called 'Putri Tunjong Bueh' $^{\prime}$ by him. San Si Perba got four children. The emperor of China sends a delegation to Palembang, to ask the hand of one of his daughters for marriage. The envoy of this delegation got the ruler's assent, that his oldest daughter would become the emperor's wife. She sailed to China. But the ruler gave Putri Tunjong Bueh in marriage to the young envoy. Many authors tell that the young Chinese, who married Putri Tunjong Bueh, was appointed by Sang Si Perba to the ruler of Palembang's inland and of all Chinese in Palembang. All rulers of Palembang are decended from him up to this day. Also the saga of Banjarese Putri Junjung Buhi (or Buih) shows the same characteristics: the princess in the foam, floating down from the upper waters of a river, her husband from a kingdom beyond of the sea, from Majapahit, emerging sitting in a gong at the mouth of Barito river.

The more ancient the source and tradition about this ancestress, the more it is domiciled in the west of Southeast Asia, the nearer it is to India and Hinduism. Thus Ras insist on the connection with the Indian goddess Lakshmi. ${ }^{10}$ According to Wikipedia Lakshmi in a legend "appeared at the creation floating over the waters on the expanded petals of the lotus flower; she is also regarded as wife of Surya, ... as one of the nine Saktis of Vishnu, ....as identified ...with Sita, wife of Rama, and with other women." 11

Palembang and Johor which dominated East Sumatra until the frontier of Minangkabau in the 16th and 17 th century ${ }^{12}$ are regions of origin from where the legend of Putri Junjung Buih entered Borneo.

1 Lembaga Pengembangan... 2003: 15; Lembaga Pengembangan... 2002: 27, 30; Baier (2008): 44, 45; Mahin 2009: 217, 218 , $334,335$. Pijnappel 1859.

Pijnappel 1859: 305, 343; Riwut 2003.

Pijnappel 1859: 282, 304.

Formerly "Pembuang", because Raja Tanga was expelled from this area, as well as some time later he must flee from Sampit to Java.

Pijnappel 1859: 304, 311.

6 Pijnappel 1859: 278, 304.

7 Eisenberger 1936: 4; Schwaner 1853 (vol. I): 45, 46; Rees I 1865: 14, 15; Cense 1928: 14, 15, 125-128; Ras1968: 27, 29, 60-62, $93,94$.

8 Sejarah Melayu: Overbeck 1927: 131, 132 and Mees 1935: 34, 35; Ras 1968: 86.

9 word by word translated from ancient Malayan: The princess, the lotus in the foam, in modern Indonesian: The princess, lifted up by the foam.

$10 \quad$ Ras 1968: 439; 1973: 184, 185.

11 Wikipedia "Lakshmi".

12 Cribb 2000: 80, 81. 
Because there are several other important names of deities originating from Hinduism as Mahatara, dewa, dewata, Jata, Naga a.s.o., some main notions don't originate from the Dayaks but are adopted from Indian Hinduism. The tradition is still alive, that the Tumon Dayaks from Delang and Blantikan river immigrated from the Minangkabau area. ${ }^{13}$ It is fairly obvious inference, that these influences from India and western Southeast Asia began to enter Kalimantan during the thalassocrazy of the Srivijaya empire and its non-islamic successsion states.

Now then, we find the Putri Junjung Buih legend and its characteristics in many so called "high cultures" of coastal kingdoms in the Malay Peninsula, Sumatra and Borneo. But do we find them also in tribal cultures without any script? Hans Schaerer was probably the only scholar who tried to find the structuralism of ancient Javanese and Balinese cultures in a tribal culture, in the Dayak Ngaju culture. ${ }^{14}$ But Schaerer failed totally in his endeavor. The repeated ritual verses with other words are not relative to two moieties of the Ngaju tribe but to the art of recitatives of Ngaju ritual poetry. ${ }^{15}$

Otherwise we find the mythologem or the Putri Junjung Buih legend exactly in the myth of origin of the Ngaju. The Ngaju name of the ancestress in the ritual language ("Bahasa Sangiang") is: "Kameloh Putak Bulau Janjulen Karangan, Limut Batu Kamasan Tambun”, free transcribed: "The Princess in the golden foam which came from the upriver rubble", - second phase of the ritual name with other words: "of the grease which came from the jeweled stones from the Nagadragon". This ancestress really entered the world on the rocks at the upper waters of the river, then floated downriver with a boat until the mouth of the river. There she met the male ancestor "Manyamei Tunggul Garing Janjahunan Laut, Sahawung Tangkuranan Hariran", free transcribed: "The Great-Grandfather, the stump of the ivory-tree which emerged from the sea, the godlike Sahawung from the manifolded treasures of the sea". This ancestor entered the world in the sea and sailed with a boat to the coast, where he met the Kameloh. ${ }^{16}$

Thus, when we consider sources and their information about the past, we are able to widen our horizon and would be saved from onesidedness and faults. We see, this stands also for the knowledge of one's own culture, especially when there are no written sources about the past as in script religion and culture of the Dayak Ngaju tribe.

The second source only gives a very short notice about an established custom which belongs to the service of the priestesses ("blian" or "balian") of the Dayak Ngaju tribal religion : to be available as hierodules during their ritual feasts. The German missionary Denninger reports $1853^{17}$ : The widow of a chief in the Paju Epat village Murutuwu ${ }^{18}$ Jaar in Patei because the people of Sihong" (former identical with Paju Epat) "don't have prostitute-blians." That is true, the priestesses of all Ma'anyan tribes are married women who live in their families with their own children.

In the 1840-years these "bilians" (so Schwaner) were common prostitutes in the Ngaju Area (Lower Barito, Pulau Petak, Kapuas and Kahayan river) besides their tasks in the Cult prostitution/sacred fornication. They were respected, even esteemed, in society ${ }^{19}$. The earlier German missionaries (before the Banjarese War) compare them with the Javanese "ronggings" 20 . Ronggengs are singing and dancing girls in Java who perform in village and family festivities. Apparently, they were available as prostitutes during these festivities in the 19th century. The Christian retired teacher Ikat in Kuala Kapuas-Dahirang told me in 1969, that he in young days was seduced by a balian prostitute $^{21}$. Wikipedia without clinching arguments from the past writes: "In the past the erotic and sexual nuance of the dance gave ronggeng a shady reputation as prostitution disguise in the art of

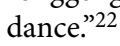

It is evident, that in the directly adjacent neighbouring areas of the Ngaju (East and upper Barito, upper Kapuas and upper Kahayan river, the entire Katingan river) there was no Cult prostitution. The abovementioned village of Jaar is the "gateway" to the Ma'anyan area from Banjarmasin and the coast. And just there was the residence of the own prostitute-balian for the Ma'anyan region. There at any rate didn't exist any relationship to the Ngajus and their tribal religion. Thus this available prostitute got her pattern from the coast and from Java. Hence we may infer, that the Cult prostitution was not an original establishment of the Ngaju culture, but it was introduced from Java. The more Islam and Christianity were propagated in Central Kalimantan, the more this sacred fornication declined. Approximately it died out in the first quarter of the 20th century ${ }^{23}$.

It stands to reason that nobody likes to hear or read dark and unpleasant facts of the history of his native land. No Indonesian scholar mentions this sacred fornication in his publications. When author as a lecturer of Dayak culture and history touch upon this Cult prostitution in my teaching or writing, Author confesses as a German person whose nation killed six million Jewish people by poison gas $^{24}$. But than author dared to write or teach about this unpleasant establishment that belongs to the history of Ngaju culture. That notwithstanding a Javanese lady from the famous conservative House of the Solo Sultanate touch upon the balian prostitutes, not to give information about this institution, but to pillory the German missionaries. This scholar writes in one of her newest essays: the "ritual performances take the whole night. Therefore they (these priestesses) were connected by the missionaries with the 'sacred fornication' and were called 'un-christian'"25. Formerly she claimes, that Schaerer interpretes these nights like worship prostitution and from his remarks

\footnotetext{
13 Mallinckrodt 1924: 399; Kato 1997: 620.

14 Schaerer 1969, n.d.

15 Baier 1987: XII,XV; 2003: 69; 2008: 31.

16 Simpei, Bajik R. 1996: 26-34; Baier 2000: 67; (2008): 46-51; Lembaga Pengembangan Tandak...2003, Kelas I: 31-33, Kelas III: 37.

17 Berichte des Rheinischen Missionsgesellschaft 1854: 341.

18 Hudson 1976: 27, 28.

19 Schwaner 1853 I: 185, 186, II:114; Adatrechtbundels 1917: 132.

20 Hupe 1846: 142, Hardeland 1859: 35; also Halewijn 1832: 285, 286.

21 Personal communication, written in my notebook under "Balian".

22 Wikipedia "Ronggeng".

23 cf. Mallinckrodt 1925:535 (NB “oudtijds"); Zimmermann 1969 mentioned nothing about worship prostitution in his famous essay.

24 Baier 2008: 24; Maiullari 2010:310.

25 Sri Kuhnt-Saptodewo/Mahin 2009: 144.
} 
Citation: Baier PM (2017) The Importance of Dutch and German 19th Century Sources. J Anthropology Rep 2: 1000115.

Page 3 of 3

(1966!) it was adopted in the anthropological literature. It was ignored that many non-missionaries like colonial officers and military doctors in the 19th century reported about these balian prostitutes. The "interpretations of the German missionaries are straitened by their Eurocentric feelings" and their "religious fancies". 26

Thus the Cult prostitution is periodic and tribal limited exclusively in the Ngaju culture. It was introduced from outside and pent up by the influence of other foreign religions. To reach these findings one must consider the sources of the 19 th and beginning 20 th century.
Alas, there are West-European anthropologists who never consider such sources and publish especially geographic errors in their publications. This small essay would give hints, that for a serious scientific publiccation such sources had to be checked and studied.

Rev. Dr. phil. Martin Baier, guest lecturer in Samarinda, residence in Germany.

26 Sri Kuhnt-Saptodewo 1993: 60, 329. 